\title{
DISTRIBUTION AND HABITAT PREFERENCE OF SLOTH BEAR IN CHITWAN NATIONAL PARK, NEPAL
}

\author{
DINESH GHIMIRE ${ }^{1} \otimes$ AND TEJ BAHADUR THAPA ${ }^{1}$ \\ ${ }^{1}$ Central Department of Zoology, Tribhuvan University \\ Kirtipur, Kathmandu, Nepal \\ ghimiredinesh72@gmail.com
}

\section{ABSTRACT}

Effective conservation of Sloth bear requires detailed information regarding their distribution and habitat use. This study attempted to generate baseline data on distribution and habitat preference of Sloth Bear in Chitwan National Park, Nepal during March-May 2012. The study area was divided into 74 grids each measuring $16 \mathrm{Km}^{2}$. Of the total grids, 35 were randomly selected for occupancy sampling. A total of 288 spatial replicates were sampled in 35 different grids recording 87 direct or indirect evidences of Sloth bear. Among them, 50 diggings, 25 scats, four scrapes with live animals in eight points were detected in four different habitat types of the Park. The variance to mean ratio showed clumped distribution of Sloth bear. The RPI values revealed that the mixed forest was found to be most preferred $(R P I=0.42)$ by Sloth Bear followed by grassland $(\mathrm{RPI}=0.21)$. Riverine forest and Sal forest were less preferred ( $R P I=-0.25$ and -0.11 respectively) but not avoided. Distribution of Sloth bear was influenced by distance to nearest water sources, distance to road and altitude. Similarly, disturbances like human activities, presence of cattle and fire were found to affect the distribution of Sloth bear.

Keywords: distribution, habitat preference, Sloth bear, Chitwan

\section{INTRODUCTION}

Out of eight species of bears found in the world (Servheen, 1990), Sloth bears (Melursus ursinus, Shaw, 1791) are restricted to Nepal, Bhutan, India and Sri Lanka. In Nepal, they were formerly reported to exist across the terai and Siwalik Hill but have been extirpated in some part of the region (Garshelis et al., 1999a) and limited to the Terai region including Chitwan National Park (CNP), Parsa Wildlife Reserve (PWR), Bardia National Park (BNP) and surrounding districts of Banke, Bara, Kailali and Dang (Jnawali et al., 2011).

Sloth bears are the only myrmecophagous ursid feeds on insects (Laurie \& Seidensticker, 1977; Joshi et al., 1997). Habitat use, distribution and ranging patterns of species are influenced by the availability of food resources. Being mobile and opportunistic, bears shift their habitat in accordance with availability, abundance and distribution of dietary resources (Joshi et al., 1995; Gondalia et al., 2012). They occupy wide range of habitats including wet and dry tropical riverine forest, Sal forest, savannas and grasslands. In Nepal, Sloth bears generally move to upland Sal forest in wet season because monsoon rains hamper foraging in low lands whereas they concentrate in lower grassland areas in dry season where ants and termites are readily available (Joshi et al., 1995).

Sloth bear is listed as "Vulnerable" species by the World Conservation Union (IUCN, 1996) 
and is included in Appendix I of CITES (Convention on International Trade in Endangered Species of Wild Fauna and Flora 1995). Major threats to this species are habitat loss and poaching (Johnsingh, 2003). Depletion and fragmentation of natural habitats (Santiapillai \& Santiapillai, 1990; Rajpurohit \& Krausman, 2000), trade in body parts (Laurie \& seidensticker, 1977; Servheen, 1990; Garshelies et al., 1999a), stealing of cubs for dancing (D'Cruze et al., 2011; Satyanarayn et al., 2012) have posed serious threats to the Sloth bear populations in its entire range (Bagali et al., 2012). Sloth Bears rarely enter into the village, damage property or raid the crops (Joshi et al., 1995), human- bear conflicts mostly happen due to the encounter in forests (Pragash et al., 2012). The only natural threats to Sloth bear are tigers (Panthera tigris) and possibly leopards (Panthera paradus) (Joshi et al., 1999).

Effective conservation strategy for the Sloth bear requires detailed information on their status and distribution (Garshelis et al., 1999a). In the past, some appreciable research works have been carried out on Sloth bear ecology and brought the remarkable results on the species in CNP (Laurie and Seidensticker, 1997; Joshi et al., 1995, 1997,1999). But since then, monitoring Sloth bear status in CNP Nepal has been neglected. However, Sloth bears are considered as an indicator of healthy carnivore communities and conservation challenges may be effectively addressed using the Sloth bear as a surrogate for conservation (Simberloff, 1999; Ratnayeke \& Menon, 2012). This study aimed to: assess the distribution pattern, habitat preference and determine the factors affecting distribution of Sloth bear in CNP.

\section{MATERIALS AND METHODS}

\section{Study area}

The study was carried out in Chitwan National Park, a world heritage site, situated in the south central Nepal. The park covers an area of $932 \mathrm{~km}^{2}$ and characterized by three seasons: hot summer, monsoon and short cold winter season. The climate is subtropical with relatively high humidity. The mean annual rainfall between 2001 and 2010 was $1520 \mathrm{~mm}$. More than $90 \%$ of the total rainfall occurs within five months i.e., May to September.

Vegetation in CNP mainly comprises Sal (Shorea robusta) forest, grassland, mixed and riverine forest. Sal is the dominant species attaining a maximum height of $30 \mathrm{~m}$. The CNP harbors exceptionally diverse wildlife population. The Park is the home to more than 68 species of mammals, over 545 species of birds and 55 species of amphibians and reptiles (DNPWC, 2010).

\section{Data collection}

The field work was carried out in dry season during March to May, 2012 to collect evidences of Sloth bear. The study area was divided into equal grids each measuring $16 \mathrm{Km}^{2}$ using ARC GIS 9.2; approximately the home range size of the species (Hines et al., 2010). Of the 74 grids generated, 35 grids (47\%) were randomly selected to sample Sloth bear evidences (fig. 1). Transect measuring a distance of $1.5 \mathrm{~km}$ to $8.5 \mathrm{~km}$ was surveyed in each grid, and data were collected in every $500 \mathrm{~m}$ spatial replicates. Both direct sightings as well as indirect signs of the bear such as diggings, scats and scrapes were recorded. 


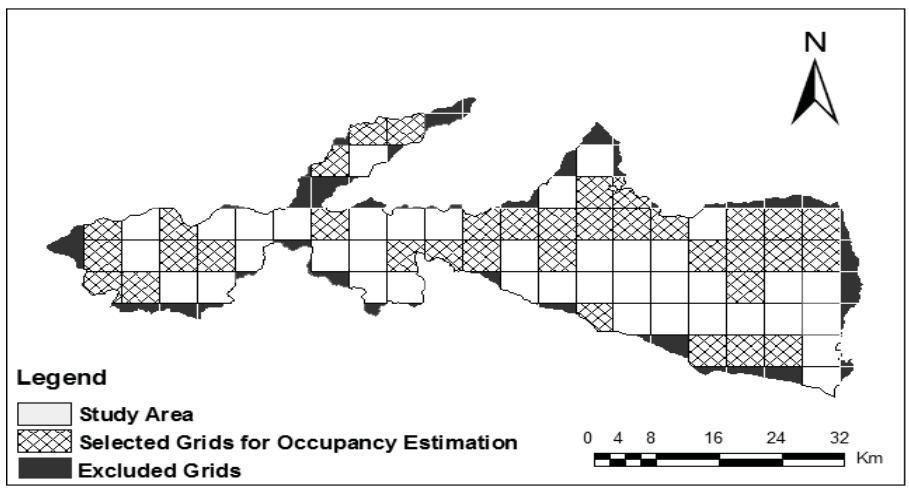

FIG.1. Map showing selected and excluded grids in the study area.

During field works factors affecting Sloth bear distribution were recorded. Measurable factors such as habitat types, altitudinal gradients and anthropogenic disturbances with their intensities were recorded in each segment of the transect. In addition, proximate variables such as distance to water sources, distance to road and distance to settlements were also estimated using the ARC GIS. The habitat type was generalized as Sal forest, mixed forest, grassland and riverine forest based on the latest land cover map of CNP (Thapa, 2011) and major vegetation associations. GPS readings were recorded on each segment for measuring altitudinal range. Sign frequencies of indicators of human disturbances such as fire, cut and broken stem, and cattle grazing and dung were recorded in each spatial replicates to infer the anthropogenic disturbances.

\section{Data analysis}

Distribution pattern

Sloth bear signs such as diggings, scats and scrapes were considered the presence of the bear on that particular area. Data on animal locations were recorded in each habitat type and used to determine the distribution pattern. The distribution pattern was calculated by variance to mean ratio (Odum, 1996) which is based on the fact that in Poisson distribution, the variance $\left(S^{2}\right)$ is equal to the mean.

Chi-square test for goodness-of-fit ( $\chi^{2}-$ test): A chi-square goodness-of-fit test was used to determine whether the direct or indirect signs of Sloth bear were distributed significantly in four different habitat types. The test was performed by setting hypothesis that the Sloth bear was uniformly distributed in all habitat types in CNP.

Habitat Preference

The data for presence or absence of the species in each segments of transect was used to determine the habitat preference of the Sloth bear. Relative preference indices were calculated by following the method of Stinnet \& Klebenow (1986) to examine habitat preference of the

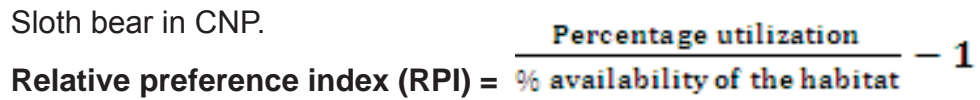


Positive values of RPI indicate preference, negative values between 0 and -1 indicate no preference, and -1 indicates no use.

Chi-square test for goodness-of-fit $\left(\chi^{2}-\right.$ test): A chi-square goodness-of-fit test was used to determine any significant difference in the preference of different habitats. The test was performed by setting hypothesis that there was no significant difference in the preference among different habitats.

\section{RESULTS}

A sampling effort of $183 \mathrm{~km}$ of transects walk in 35 grids yielded 87 evidences of Sloth Bear presence. Most frequently detected sign was dug out insect moulds $(n=50)$ followed by scat $(n=25)$. Live animals were observed in eight different locations and four scrapes were found. Of the total grids surveyed, bear sign was not detected in 11 grids which were located near Triveni in the west, Thori and Amuwa post in the south east region of the park (fig. 2).

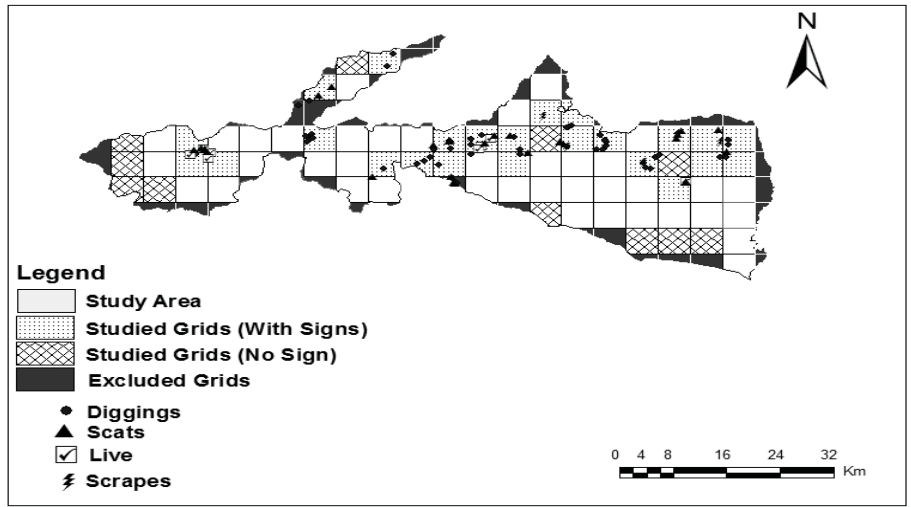

FIG. 2. Different evidences found in studied grids.

\section{Distribution pattern}

Most of Sloth bear signs evidences (54\%) were were located in Sal, followed by mixed forest (25\%), riverine forest (8\%) and grassland (13\%) (fig.3). It was so because $61.1 \%$ of total replicates were specified to Sal forest.

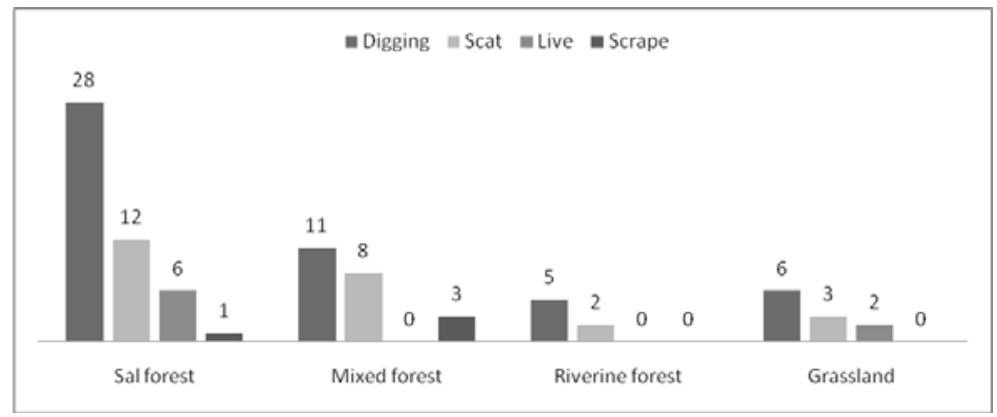

FIG. 3. Number of signs found (habitat wise). 
The Sloth bear signs were encountered in almost all types of habitat. However, the calculation of variance to mean ratio showed clumped distribution pattern of Sloth bear $\left(\mathbf{S}^{2} / \overline{\mathrm{XX}}=11.15>\right.$ 1 ). The chi-square test also showed uneven distribution $\left(\chi^{2}=11.1, p=0.01\right.$ and 0.05 , $\left.d f=3\right)$.

\section{Habitat preference}

CNP is the complex of different types of forest systems. In this study, mainly four types of habitats namely Sal forest, mixed forest, riverine forest and grassland were considered as habitat sites. Out of total 288 locations surveyed, 176 points lied on Sal forest, 51 points on mixed forest, 31 on riverine forest and 30 points were recorded in grassland.

The RPI values revealed that the mixed forest was found to be most preferred $(\mathrm{RPI}=0.42)$ by Sloth bear followed by grassland $(\mathrm{RPI}=0.21)$. Riverine forest and Sal forest were less preferred by the species (RPI=-0.25 and -0.11 respectively) but not totally avoided (fig. 4 ).

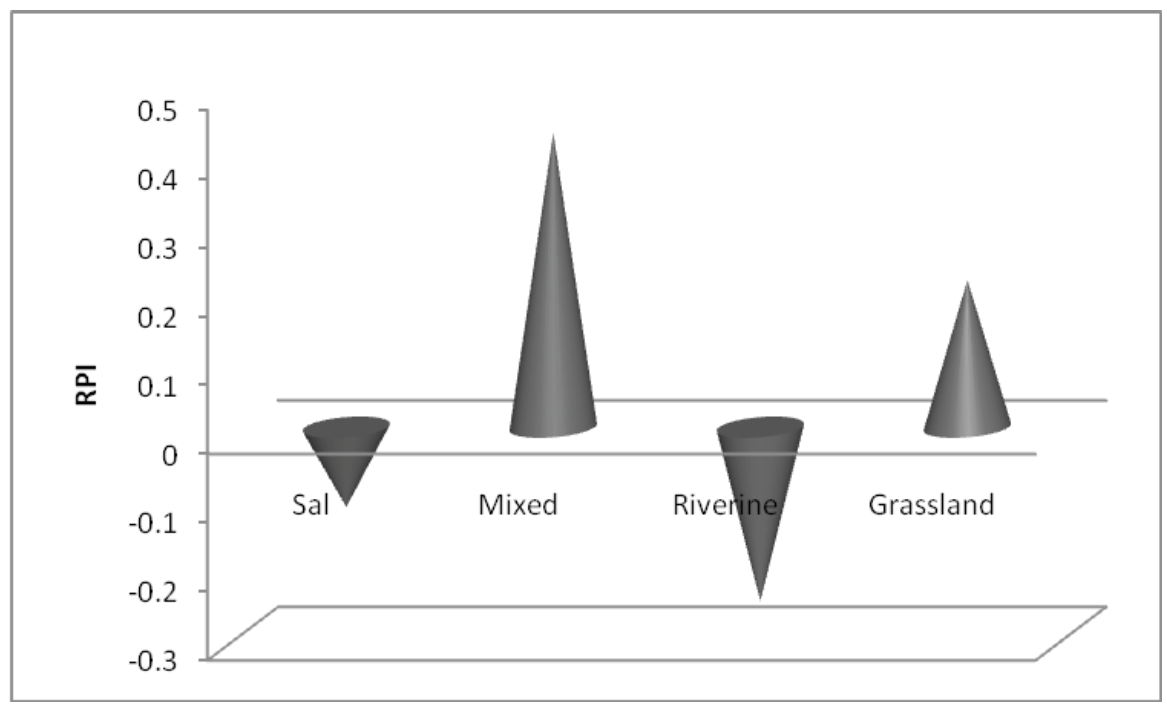

FIG. 4. Relative preference indices (RPI) of different habitat types for dry season (2012).

Regardless of the RPI values, Chi-square contingency test showed no significance difference in using different habitat types by Sloth bear $\left(\chi^{2}=4.21, p=0.05\right.$, df $\left.=3\right)$.

\section{Factors affecting distribution}

Variables such as distance to water sources, distance to road, distance to settlement, altitudinal variations and disturbances were considered the factors that could influence the distribution of the species. 
TABLE 1. Detections of Sloth bear sign in response to different variables.

\begin{tabular}{|c|c|c|c|c|c|}
\hline Variables & Distance (meter) & $\begin{array}{c}\text { No. of } \\
\text { detection }\end{array}$ & Variables & $\begin{array}{c}\text { Distance } \\
\text { (meter) }\end{array}$ & $\begin{array}{c}\text { No. of } \\
\text { detection }\end{array}$ \\
\hline \multirow{5}{*}{$\begin{array}{l}\text { Water } \\
\text { Sources }\end{array}$} & $<500$ & 40 & \multirow{10}{*}{ Settlement } & $1000-2000$ & 0 \\
\hline & $501-1000$ & 21 & & 2001-3000 & 17 \\
\hline & $1001-1500$ & 17 & & $3001-4000$ & 14 \\
\hline & $1501-2000$ & 6 & & $4001-5000$ & 19 \\
\hline & $>2000$ & 3 & & $5001-6000$ & 10 \\
\hline \multirow{7}{*}{ Road } & $<500$ & 9 & & $6001-7000$ & 13 \\
\hline & $501-1000$ & 5 & & $7001-8000$ & 5 \\
\hline & $1001-1500$ & 5 & & $8001-9000$ & 3 \\
\hline & $1501-2000$ & 10 & & $9001-10000$ & 0 \\
\hline & $2001-2500$ & 5 & & $>10000$ & 6 \\
\hline & $2501-3000$ & 1 & \multirow{2}{*}{ Altitude } & $<300$ & 78 \\
\hline & $>3000$ & 52 & & $>300$ & 9 \\
\hline
\end{tabular}

About $46 \%$ of detections were recorded within 500 meter distance from water sources. Only 3 signs of Sloth bear were found more than $2 \mathrm{~km}$ far from any water sources (table 1). Similarly, $60 \%$ of the signs were found more than $3 \mathrm{~km}$ far from the roads. About $90 \%$ of Sloth bear Signs were recorded within the altitude of 300 meter. Out of total 288 locations surveyed, 63 signs of human presence, 21 signs of fire and 20 signs of cattle/cattle dung were noted. Among them, Sloth bear was not detected in $51 \%$ of those points where human presence was recorded. Similarly, Sloth bear signs were absent in $95 \%$ of those points where fire activities were found. $75 \%$ of area where cattle signs found was not occupied by Sloth bear.

\section{DISCUSSION}

\section{Distribution pattern}

The distribution of Sloth bear in Chitwan National Park showed clumped pattern in dry season. Similarly, the Chi-Square test showed uneven distribution in the area ( ${ }^{2}=11.1, p=0.01$ and 0.05 , $d f=3$ ). The clumped pattern of distribution is most common in nature because of the aggregation of individuals in response to various factors such as habitat differences, daily or seasonal weather changes, reproductive processes or the social attractions (Odum, 1996). In nature the resources such as food availability, water sources and cover are not distributed uniformly leading to the uneven distribution of the species.

Being mobile and opportunistic, Sloth Bears shift their area of use in accordance with the distribution of food. Seasonal movements corresponding with changes in food availability is 
very common in Sloth bear. By the beginning of dry season, Sloth bears generally aggregate in grassland due to hard soil condition in upland forest which impedes bears ability to excavate termite mounds (Joshi et al., 1995). In the case of Chitwan National Park, there is sharp segregation of different habitats which provide the food for Sloth bear year-round (Garshelis et al., 1999a). Clumped pattern of distribution resulted due to the tendency of Sloth bear to visit areas where food availability is relatively higher.

\section{Habitat preference}

Sloth bear showed high preference of Mixed forest $(\mathrm{RPI}=0.42$, followed by grassland $(\mathrm{RPI}=0.21)$ whereas Sal forest and riverine forest were less preferred (RPI $=-0.11$ and -0.25 respectively). Though ursids have large home ranges and distinct seasonal shifts, Sloth bears cover variable distances of different land patches in search of water and food (Chauhan et al., 2010). Laurie \& Seidenstiker (1977) reported that seasonal variations in habitat use by Sloth bear are associated with fruit availability. During non-fruiting season, Sloth bear concentrate on grassland where ants and termites are readily available. In contrast, Joshi et al. (1997) suggested that movements of bear from grassland to upland are not stimulated by fruiting alone, but saturated ground due to monsoon rain hamper foraging in the grasslands compel bears to move to elevated areas. Similarly, for bears that move to upland Sal forest migrate back to grassland because of the dry, hard soil condition in Sal forest hinder it to dig termite colonies (joshi et al., 1995). Thus, habitat preference of Sloth bear is determined by the availability of ants and termite colonies which differ in different type of forest with seasonal variations.

Furthermore, various studies (Baskaran, 1990; Santiapillai \& Santialillai, 1990; Garshelis et al., 1999a; Yoganand et al., 2006; Ratnayeke et al., 2007) revealed that Sloth bears prefer areas having less human disturbances. Sloth bear signs were not detected in the present study where high human disturbances prevalent.

\section{Factors affecting distribution}

Prior studies in CNP by Laurie \& Seidensticker (1977) and Joshi et al. (1997) reported the movement of Sloth bear was related with the availability of either fruits or insects. It has been observed that shifting behavior of the species is shaped by the level of anthropogenic and other disturbances on their habitat. It ultimately effects their seasonal distribution as well. The distribution pattern of Sloth bear showed that they prefer areas near to water body. There was decreased number of detections with increasing distance to water sources. Roads inside the park were also found to influence the distribution of Sloth bear. Out of 87 evidences, 52 were found more than $3 \mathrm{~km}$ far from the road. In CNP, Sloth bears were distributed up to the elevation of $300 \mathrm{~m}$ though they were recorded in the elevation of $1700 \mathrm{~m}$ in India.

A survey across lowlands of Nepal indicated that Sloth bears were either absent or occurred in low densities in areas with high human use, despite high termite densities (Garshelis et al., 1999b). In this study, similar result was found in which bear activities were either nil or very few in highly disturbed area. Disturbance especially due to fire caused serious threat to the species. No sign of Sloth bear was found in the westernmost part of the park where the forest was destroyed by fire. Similarly, Sloth bear signs were not detected in the south eastern part of the Park where cattle grazing was very frequent. 


\section{ACKNOWLEDGEMENTS}

We are thankful to the Chitwan National Park (CNP) for financial support and logistics during the field work and the Department of National Parks and Wildlife Conservation for permitting us to conduct this study in CNP. Our sincere gratitude to Dr. Jhamak Bahadur Karki, then Chief Conservation Officer and Mr. Tika Ram Poudel, Assistant Conservation Officer, CNP, for their support. We extend our thanks to Dr. Naresh Subedi, Mr. Baburam Lamichhane, Mr. Amir Maharjan, Mr. Kanchan Thapa, Mr. Harka Man Lama and Bishnu Lama for their support and help. We are also grateful to Game scouts and Mahuts of CNP for their tireless help during our research. It is pleasure to express our special thanks to Captains Umesh Khadka, Prabhat Thapa and Krishna Bhandari of Rana Dal Battalian for arranging army personnel during the field work. Without their help, the study would not have been possible in western region.

\section{REFERENCES}

BARGALI, H S; AKHTAR, N; CHAUHAN, N P S (2012) The Sloth bear activity and movement in highly fragmented and disturbed habitat in central India. World Journal of Zoology 7(4): 312-319.

BASKARAN, N (1990) An ecological investigation on the dietary composition and habitat utilization of Sloth bear (Melursus ursinus) at Mudumalai wildlife sanctuary, Tamil Nadu (south India). Thesis, A.V.C. College, Mannambandal, Tamil Nadu, India.

CHAUHAN, N P S; BARGALI, H S; AKHTAR, N (2010) Radio-telemetry study on Sloth bears in India. Telemetry in Wildlife Science 13(1).

D'CRUZE, N; SARMA, U K; MOOKERJEE, A; SINGH, B; LOUIS, J; MAHAPATRA, R P; JAISAWAL, V P; ROY, T K; KUMARI, I; MENON, V (2011) Dancing bears in India: a Sloth bear status report. Ursus 22(2): 99-105.

DNPWC (2001) Royal Chitwan National Park and Buffer Zone Management Plan (2001-2005). DNPWC, Nepal.

DNPWC (2010) Annual Report. DNPWC, Nepal.

GARSHELIS, D L; JOSHI, A R; SMITH AND, J D L; RICE, C G (1999a) Sloth bear conservation action plan. In Servheen, C; Peyton, B (eds) Bears: status survey and conservation action plan, IUCN/SSC bear and polar bear specialist groups. IUCN, Gland, Switzerland; pp. 225-240.

GARSHELIS, D L; JOSHI, A R; SMITH, J D L (1999b) Estimating density and relative abundance of Sloth bears. Ursus 11: 87-98.

GONDALIYA, H; JOSHI, J V; DHARAIYA, N (2012) Evaluation of Sloth bear habitat and food availability in Jassore Wildlife Sanctuary, Gujarat, India. (Abs) $21^{\text {st }}$ International Conference on Bear Research and Management Nov. 26-30: 225.

HINES, J E; NICHOLS, J D; ROYLE, J A D; MACKENZIE, I; GOPALASWAMY, A M; SAMBAKUMAR, N; KARANTH, K U (2010) Tigers on trails: occupancy modeling for cluster sampling. Ecological Applications 20(5): 1456-1466. http://dx.doi.org/10.1890/09-0321.1.

IUCN (1996) IUCN Red List of Threatened Species. Version 2011.2. http:// www.iucnredlist.org. accessed on 09 February, 2012.

JNAWALI, S R; BARAL, H S; LEE, S; ACHARYA, K P; UPADHYAY, G P; PANDEY, M; SHRESTHA, R; JOSHI, D; LAMICHHANE, B R; GRIFFITHS, J; KHATIWADA, A P; SUBEDI, N; AMIN, R (2011) The status of Nepal mammals: The national red list series, Department of National Parks and Wildlife Conservation 
Kathmandu, Nepal. 70 p.

JOSHI, A R; GARSHELIS, D L; SMITH, J D L (1995) Home range of Sloth bear in Nepal. implication for conservation. The Journal of Wildlife Management 59(2): 204-214.

JOSHI, A R; GARSHELIS, D L; SMITH, J D L (1997) Seasonal and habitat related diets of Sloth Bear in Nepal. Journal of Mammalogy 78(2): 584-597.

JOSHI, A R; GARSHELIS, D L; SMITH, J D L (1999) Sociobiology of the myrmecophagous Sloth bear in Nepal. Canadian Journal of Zoology 77:1690-1704.

LAURIE, A; SEIDENSTICKER, J (1977) Behavioural ecology of the Sloth bear. Journal of Zoology 182(2): 187-204.

ODUM, E P (1996) Fundamentals of ecology. Nataraj Publishers, Dehradun, India (3rd edition).

PRAGASH, V S J; RATNANAYEKE, S; PIERIS, R MANEN, F T V (2012) Human Sloth bear conflicts in Sri Lanka. (Abs) 21 $1^{\text {st }}$ International conference on Bear Research and Management Nov. 26-30: 72.

RAJPUROHIT, K S; KRAUSMAN, P R (2000) Human-Sloth bear convicts in Madhya Pradesh, India. Wildlife Society Bulletin 28: 393-399.

RATNAYEKE, S; MANEN, F T V (2012) Assessing Sloth bears as surrogates for carnivore conservation in Sri Lanka. Ursus 23(2): 206-217.

RATNAYEKE, S; MANEN, F T V; PIERIS, R; PRAGASH, V S J (2007) Landscape characteristics of Sloth bear range in Sri Lanka. Ursus 18: 189-202.

Santiapillai, A; Santiapillai, C (1990) Status, distribution and conservation of Sloth bear in Sri Lanka. Tiger Paper 1: 13-15.

SATYANARAYN, K; SHESHMANI, G; SHARP, T (2012) Poaching and trade of Sloth bear cubs along Indo-Nepal Border and use of porous border as a concealment tool by poachers and traders. (Abs) $21^{\text {st }}$ International conference on Bear Research and Management Nov. 26-30: 53.

SERVHEEN, C (1990) Status and conservation of the bears of the world. International Conference on Bear Research and Management. Monograph Series 2. 32 p.

SIMBERLOFF, D (1999) Biodiversity and bears:a conservation paradigm shift. Ursus 11: 21-28.

STINNET, D P; KLEBENOW, D A (1986) Habitat use of irrigated lands by California quail in Nevada. Journal of Wildlife Management 50: 365-372.

THAPA, T B (2011) Habitat suitability evaluation for Leopard (Panthera pardus) using remote sensing and GIS in and around Chitwan National Park, Nepal. PhD dissertation, Saurasthra University, Rajkot, Gujrat, India.

YOGAN; RICE, K C G; JOHNSINGH, A J T; SEIDENSTICKER, J (2006) Is the Sloth bear in India secured? A preliminary report on distribution, threats and conservation requirements. Journal of Bombay Natural History Society 103(2-3): 172-181. 